\title{
Prevalence of germline pathogenic BRCA1/2 variants in sequential epithelial ovarian cancer cases
}

DOI:

10.1136/jmedgenet-2018-105792

\section{Document Version}

Accepted author manuscript

Link to publication record in Manchester Research Explorer

\section{Citation for published version (APA):}

Morgan, R., Burghel, G., Flaum, N., Bulman, M., Clamp, A., Hasan, J., Mitchell, C., Schlecht, H., Woodward, E., Lalloo, F., Crosbie, E., Edmondson, R., Wallace, A. J., Jayson, G., \& Evans, D. G. (2019). Prevalence of germline pathogenic BRCA1/2 variants in sequential epithelial ovarian cancer cases. Journal of Medical Genetics. https://doi.org/10.1136/jmedgenet-2018-105792

Published in:

Journal of Medical Genetics

\section{Citing this paper}

Please note that where the full-text provided on Manchester Research Explorer is the Author Accepted Manuscript or Proof version this may differ from the final Published version. If citing, it is advised that you check and use the publisher's definitive version.

\section{General rights}

Copyright and moral rights for the publications made accessible in the Research Explorer are retained by the authors and/or other copyright owners and it is a condition of accessing publications that users recognise and abide by the legal requirements associated with these rights.

\section{Takedown policy}

If you believe that this document breaches copyright please refer to the University of Manchester's Takedown Procedures [http://man.ac.uk/04Y6Bo] or contact uml.scholarlycommunications@manchester.ac.uk providing relevant details, so we can investigate your claim.

\section{OPEN ACCESS}




\section{Prevalence of germline pathogenic BRCA1/ 2 variants in sequential epithelial ovarian cancer cases}

\begin{tabular}{|c|c|}
\hline Journal: & Journal of Medical Genetics \\
\hline Manuscript ID & jmedgenet-2018-105792.R1 \\
\hline Article Type: & Original Article \\
\hline $\begin{array}{r}\text { Date Submitted by the } \\
\text { Author: }\end{array}$ & 14-Dec-2018 \\
\hline Complete List of Authors: & $\begin{array}{l}\text { Morgan, Robert; Christie NHS Foundation Trust, Department of Medical } \\
\text { Oncology; University of Manchester , Division of Cancer Sciences, Faculty } \\
\text { of Biology, Medicine and Health } \\
\text { Burghel, George; Manchester University NHS Foundation Trust, } \\
\text { Manchester Centre for Genomic Medicine } \\
\text { Flaum, Nicola; Christie NHS Foundation Trust, Department of Medical } \\
\text { Oncology; University of Manchester, Division of Cancer Sciences, Faculty } \\
\text { of Biology, Medicine and Health } \\
\text { Bulman, Michael; Manchester University NHS Foundation Trust, } \\
\text { Manchester Centre for Genomic Medicine } \\
\text { Clamp, Andrew; Christie NHS Foundation Trust, Department of Medical } \\
\text { Oncology } \\
\text { Hasan, Jurjees; Christie NHS Foundation Trust, Department of Medical } \\
\text { Oncology } \\
\text { Mitchell, Claire; Christie NHS Foundation Trust, Department of Medical } \\
\text { Oncology } \\
\text { Schlecht, Helene; Central Manchester University Hospitals NHS } \\
\text { Foundation Trust, North West Genomic Laboratory Hub } \\
\text { woodward, emma; Manchester University NHS Foundation Trust, } \\
\text { Department of Clinical Genetics } \\
\text { Lallo, Fiona; Manchester University NHS Foundation Trust, Department } \\
\text { of Clinical Genetics } \\
\text { Crosbie, Emma; Manchester University NHS Foundation Trust, } \\
\text { Department of Gynaecological Oncology; University of Manchester, } \\
\text { Division of Cancer Sciences, Faculty of Biology, Medicine and Health } \\
\text { Edmondson, Richard; Manchester University NHS Foundation Trust, } \\
\text { Department of Gynaecological Oncology; University of Manchester, } \\
\text { Division of Cancer Sciences, Faculty of Biology, Medicine and Health } \\
\text { Wallace, Andrew ; Manchester University NHS Foundation Trust, } \\
\text { Manchester Centre for Genomic Medicine } \\
\text { Jayson, Gordon; Christie NHS Foundation Trust, Department of Medical } \\
\text { Oncology; University of Manchester, Division of Cancer Sciences, Faculty } \\
\text { of Biology, Medicine and Health } \\
\text { Evans, D Gareth; Manchester University NHS Foundation Trust, } \\
\text { Department of Clinical Genetics; University of Manchester , Division of } \\
\text { Evolution and Genomic Sciences, Faculty of Biology, Medicine and Health }\end{array}$ \\
\hline Keywords: & ovarian cancer, BRCA1, BRCA2, germline, Screening \\
\hline
\end{tabular}




\section{SCHOLARONE ${ }^{\text {W }}$ Manuscripts}


1

2

3

4

5

6

7

8

9

10

11

12

13

14

15

16

17

18

19

20

\section{Prevalence of germline pathogenic $B R C A 1 / 2$ variants in}

\section{sequential epithelial ovarian cancer cases}

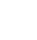

Robert D. Morgan ${ }^{1,2}$, George J. Burghel ${ }^{3}$, Nicola Flaum ${ }^{1,2}$, Michael Bulman ${ }^{3}$, Andrew R.

Clamp $^{1}$, Jurjees Hasan ${ }^{1}$, Claire Mitchell ${ }^{1}$, Helen Schlecht ${ }^{3}$, Emma R. Woodward $^{3}$, Fiona

Lalloo $^{3}$, Emma J. Crosbie ${ }^{2,4}$, Richard J. Edmondson ${ }^{2,4}$, Andrew J. Wallace ${ }^{3}$, Gordon C.

Jayson $^{1,2}$, D. Gareth R. Evans ${ }^{3,5 *}$

8

\section{Affiliations:}

10

1. Department of Medical Oncology, The Christie NHS Foundation Trust, Manchester, United Kingdom

2. Division of Cancer Sciences, Faculty of Biology, Medicine and Health, University of Manchester, Manchester, United Kingdom

3. Manchester Centre for Genomic Medicine, St Mary's Hospital, Manchester University NHS Foundation Trust, Manchester, United Kingdom

4. Department of Obstetrics and Gynaecology, St Mary's Hospital, Manchester University NHS Foundation Trust, Manchester, United Kingdom

5. Division of Evolution and Genomic Sciences, Faculty of Biology, Medicine and Health, University of Manchester, Manchester, United Kingdom 
*Corresponding author:

22

Professor D. Gareth R. Evans, MD, FRCP

Division of Evolution and Genomic Sciences,

24 Faculty of Biology, Medicine and Health,

25 University of Manchester,

26 Manchester, United Kingdom

27 Email: Gareth.Evans@mft.nhs.uk

28

Word count:

247 (abstract)

30

3,105 (article)

References:

48

32 Tables:

7

33 Figures:

0

34 Keywords: ovarian cancer, $B R C A 1, B R C A 2$, germline, screening

35 Contributor statement: Design and conception of study: RDM, DGRE. Data collection and 36 assembly: RDM, MB, DGRE. Data analysis and interpretation: RDM, AJW, GCJ, DGRE.

37 Writing of manuscript: RDM, GJB, NF, EJC, AJW, GCJ, DGRE. Critical review and revision 38 of manuscript: RDM, GJB, NF, MB, ARC, JH, CM, HS, ERW, FL, EJC, RJE, AJW, GCJ, 39 DGRE. Submission of manuscript: RDM

40 Funding: None declared.

41 Competing interests: None declared. 
42 Patient consent: All women included in this study provided informed verbal consent to 43 undergo germline BRCA1/2 testing.

44 Ethics approval: The germline $B R C A 1 / 2$ database is approved by North Manchester 45 Research Ethics Committee (08/H1006/77).

46 Provenance and peer-review: Not commissioned; externally peer reviewed

47 Acknowledgements: DGRE, EJC and ERW are supported by the all Manchester NIHR 48 Biomedical Research Centre (IS-BRC-1215-20007). 


\section{ABSTRACT}

51 Introduction: Poly(ADP-ribose) polymerase inhibitors significantly improve progression-

52 free survival in platinum-sensitive high-grade serous and endometrioid ovarian carcinoma, 53 with greatest benefits observed in women with a pathogenic $B R C A 1 / 2$ variant. Consequently, 54 the demand for germline $B R C A 1 / 2$ testing in ovarian cancer has increased substantially, 55 leading to screening of unselected populations of patients. We aimed to determine the 56 prevalence of pathogenic germline $B R C A 1 / 2$ variants in women diagnosed with epithelial 57 ovarian cancer, categorised according to the established risk factors for hereditary breast and 58 ovarian cancer syndrome and the Manchester BRCA Score, in order to inform risk stratification.

Methods: A cohort of sequential epithelial ovarian cancer cases recruited between June 2013 and September 2018 underwent germline BRCA1/2 testing by next-generation sequencing and multiplex ligation-dependent probe amplification.

Results: Five hundred and fifty-seven patients were screened. Of these, $18 \%$ had inherited a pathogenic $B R C A 1 / 2$ variant. The prevalence of pathogenic $B R C A 1 / 2$ variants was $>10 \%$ in women diagnosed with ovarian cancer earlier than 60 years old $(21 \%)$ and those diagnosed later than 60 years old with a family history of breast and/or ovarian cancer $(17 \%)$ or a past

67 medical history of breast cancer (34\%). The prevalence of pathogenic BRCA1/2 variants was also $>10 \%$ in women with a Manchester BRCA Score of $\geq 15$ points $(14 \%)$.

69 Discussion: Our study suggests that age at diagnosis, family history of breast and/or ovarian cancer, past medical history of breast cancer or a Manchester BRCA Score of $\geq 15$ points are associated with a $>10 \%$ prevalence of germline pathogenic $B R C A 1 / 2$ variants in epithelial ovarian cancer. 
74

75

76

77

78

79

80

81

82

83

84

85

86

87

88

89

90

91

92

93

94

95

96

97

\section{INTRODUCTION}

Ovarian cancer is the eighth most common cancer occurring in women and the second commonest cause of gynaecological-related cancer death worldwide [1]. Standard of care treatments include cytoreductive surgery and platinum- and taxane-based chemotherapy [2, 3]. Molecularly targeted agents offer the promise of anti-cancer treatments that specifically target biological vulnerabilities within tumour cells, thereby offering alternative therapies to traditional cytotoxic agents. To date, pathogenic $B R C A 1 / 2$ variants are the only predictive biomarkers validated in ovarian cancer [4]. Several phase $2 / 3$ trials have shown that poly(ADP-ribose) polymerase (PARP) inhibitors significantly improve progression-free survival (PFS) in platinum-sensitive high-grade serous and endometrioid ovarian cancer, with the greatest benefit achieved in women with a pathogenic $B R C A 1 / 2$ variant [5-10]. Indeed, a recently reported randomised, double-blinded, placebo-controlled, phase 3 trial, SOLO1, demonstrated that 24 months of olaparib maintenance therapy following a partial/complete response to cytoreductive surgery and platinum-based chemotherapy in FIGO stage 3/4 $B R C A$-mutant high-grade serous or endometrioid ovarian carcinoma reduced the risk of disease progression or death at 3 years with a hazard ratio 0.28 (95\% confidence interval $0.20-0.39, \mathrm{P}<0.001)[9]$.

91 The prevalence of germline pathogenic $B R C A 1 / 2$ variants in ovarian cancer is estimated at between 10 and $15 \%$, with the majority of heterozygotes diagnosed with high-grade serous ovarian carcinoma [11-15]. High-grade serous carcinoma is the commonest histological subtype, accounting for approximately $70 \%$ of all cases of ovarian cancer $[16,17]$. At present, access to PARP inhibitors as maintenance therapy in Europe and North America is restricted by morphological subtype (serous or endometrioid), BRCA1/2 status (germline or somatic) and/or platinum sensitivity (complete or partial response to the latest platinum-based 
therapy). It is not surprising therefore that clinical demand for $B R C A 1 / 2$ testing has increased significantly as oncologists and patients seek to access these drugs [18-23]. As a result, germline $B R C A 1 / 2$ testing is increasingly prevalent in unselected populations of women with ovarian cancer, resembling routine tumour testing for somatic mutations in other tumour types e.g. BRAF (melanoma), RAS (colorectal cancer), EGFR (lung cancer) and PDGFRA and KIT (gastrointestinal tumours). Unlike routine tumour testing for somatic variants, testing for germline $B R C A 1 / 2$ variants could be stratified according to risk factors associated with hereditary breast and ovarian cancer syndrome [24].

In this study, we report the prevalence of germline pathogenic $B R C A 1 / 2$ variants in a large cohort of women diagnosed with epithelial ovarian cancer in the North West of England, correlating the prevalence of germline pathogenic $B R C A 1 / 2$ variants with risk factors associated with hereditary breast and ovarian cancer syndrome. Our aim is to inform risk stratification for germline $B R C A 1 / 2$ testing in epithelial ovarian cancer when conducted in an oncology clinic rather than a specialised genetics department.

\section{METHODS}

\section{Patient selection}

Women diagnosed with epithelial cancer of the ovary, fallopian tube or peritoneum (FIGO stage 1 to 4 [25]) who underwent germline BRCA1 and BRCA2 testing between $1^{\text {st }}$ June 2013 and $1^{\text {st }}$ September 2018 were included. Germline $B R C A 1 / 2$ testing took place in the oncology clinics at the Christie NHS Foundation Trust, Manchester or the genetics clinics at St Mary's Hospital, Manchester. Only women treated for ovarian cancer at The Christie Hospital or St Mary's Hospital were included in the study. Pathogenic (class 5) or likely pathogenic (class 
4) BRCA1 and BRCA2 variants were included and will be referred to collectively as "pathogenic BRCA1/2 variants" throughout this manuscript, whilst variants of unknown clinical significance (class 3) were excluded [26]. Cases of non-epithelial ovarian cancer

124 were excluded. Women from a Jewish ancestry were excluded because across the North West 125 of England this group undergo founder mutation testing first, and the Manchester BRCA 126 Scoring System is not designed to assess risk in this population.

127 A family history was defined as any index case of epithelial ovarian cancer and a first-degree 128 or second-degree relative with breast and/or ovarian cancer. An index case was diagnosed with sporadic ovarian cancer if she had no first-degree or second-degree relative with breast and/or ovarian cancer. All demographic data were extracted from case notes and/or electronic

131 patient records.

\section{Survival bias}

133 In order to account for survival bias we performed a subgroup analysis according to the year 134 the index case was diagnosed with ovarian cancer (pre versus post 2012). This strategy was 135 adopted because the prevalence of pathogenic $B R C A 1 / 2$ variants detected in women 136 diagnosed with ovarian cancer before 2012 may have been biased by long-term survivors [27, 137 28]. In women diagnosed with ovarian cancer before 2012, the minimum time from the 138 diagnosis of ovarian cancer to subsequent germline $B R C A 1 / 2$ testing was 18 months (January 1392012 to June 2013); an interval that approximates to half the median overall survival for 140 ovarian cancer [17].

\section{Germline $B R C A 1 / 2$ testing}

142 Germline $B R C A 1$ and $B R C A 2$ variants were detected by testing DNA extracted from 143 peripheral circulating lymphocytes. Next generation sequencing (NGS) was used to detect 
variants throughout the whole coding sequence of $B R C A 1$ and $B R C A 2$, including at least 15 base pairs beyond each exon-intron junction. Enrichment occurred using a custom designed long range PCR based approach followed by a normalisation step using SequalPrep 147 normalisation plates and library preparation using the Illumina Nextera DNA Library 148 Preparation Kit. NGS analysis was on an Illumina MiSeq using v2 $2 \times 150$ base pair sequencing chemistry. Single nucleotide variants and small deletions, duplications, insertions and insertion/deletions ( $<40$ base pairs) were called using a bioinformatic pipeline validated to detect heterozygous and mosaic variants in NGS data to an allele fraction of $\geq 4 \%$. The bioinformatic pipeline was developed for use across a broad range of inherited cancer syndromes, some of which have a high frequency of somatic mosaicism e.g. neurofibromatosis type 2. An allele fraction cut off of $\geq 4 \%$ for variant detection was determined following clinical validation, as this was the lowest allele fraction limit of detection where both sensitivity and specificity remained high.

157 Testing for large genomic rearrangements/copy number variation (e.g. whole exon or whole gene deletions/duplications) in BRCA1 and BRCA2 was performed by multiplex ligationdependent probe amplification (MLPA) [29]. The MLPA MRC Holland probe kits P002-D1 (BRCA1) and P045-C1 (BRCA2) were used to analyse germline DNA. Amplified ligation products were subject to fragment analysis using an ABI 3130xl Genetic Analyser and size called using GeneMapper v2.0 (Applied Biosystems). Copy number status calling was performed using data exported from GeneMapper using custom developed MLPA spreadsheets that report relative dosage quotient for each probe compared to five reference control samples. All MLPA analysis assays were performed in duplicate for confirmation of 166 results. 
168 The Manchester Scoring System is a simple-to-use, paper-based model that can be used to 169 determine the combined $B R C A 1$ and $B R C A 2$ carrier probability of an index case with a 170 relevant cancer (Table 1) [30]. The development of the Manchester Scoring System was 171 based on empirical data gathered from the Manchester mutation-screening programme [31]. 172 Each individual, from one side of the family, is scored for each gene separately, $B R C A 1$ and 173 BRCA2 (Table 1). For index cases of breast cancer or any index case or unaffected relative of 174 an index case of ovarian cancer ( $<60$ years) the BRCA1 and BRCA2 scores are adjusted 175 according to pathology [30]. The pathology adjustment takes into account the higher 176 prevalence of germline pathogenic $B R C A 1 / 2$ variants in triple-negative breast cancer and 177 high-grade serous ovarian carcinoma [32]. A Manchester Score of 15-19 points equates to a 178 combined $B R C A 1$ and $B R C A 2$ probability of $10 \%$, and 20 points to a $20 \%$ probability [30].

\section{RESULTS}

Five hundred and fifty-seven women of non-Jewish ancestry underwent germline BRCA1 and BRCA2 testing following a diagnosis of epithelial ovarian cancer (Table 2). A total of 103 women (18\%) had a pathogenic BRCA1/2 variant (68 BRCA1, 35 BRCA2) (Table 2). The mean age at which ovarian cancer was diagnosed differed in patients with pathogenic $B R C A 1$ (51.9 years [range 36-76]) and $B R C A 2$ (59.4 years [range 33-86]) variants. The types of pathogenic $B R C A 1 / 2$ variants detected are reported in Table 3. Twenty-three BRCA1/2 variants of unknown clinical significance (class 3) were detected.

Pathogenic $B R C A 1 / 2$ variants were most commonly detected in women diagnosed with highgrade serous ovarian cancer, although women diagnosed with this histological subtype were 
endometrioid ovarian cancer had poorly differentiated (high-grade) tumours. No BRCA1/2 heterozygotes had low-grade serous, low-grade endometrioid, undifferentiated or mucinous ovarian cancer (Table 2) [16]. One woman diagnosed with FIGO stage 3C carcinosarcoma of 194 the ovary had inherited a germline $B R C A 1$ variant, although the epithelial histological component of her invasive tumour was high-grade serous. Eighty-four women $(15 \%)$ had been diagnosed with breast cancer and $268(48 \%)$ had a first-degree or second-degree relative with breast and/or ovarian cancer (Table 2).

The prevalence of pathogenic $B R C A 1 / 2$ variants was $>10 \%$ in women diagnosed with ovarian cancer under the age of 60 years $(21 \%)$ (Table 4$)$. Also, the prevalence of pathogenic $B R C A 1 / 2$ variants was $>10 \%$ in women diagnosed at 60 years or older with a family history of breast and/or ovarian cancer (17\%) or a past medical history of breast cancer (34\%) (Table 4). In women diagnosed with sporadic ovarian cancer at 60 years or older the prevalence of pathogenic $B R C A 1 / 2$ variants almost reached 10\% (7/76) (Table 4). However, in women diagnosed with sporadic ovarian cancer at 60 years or older without a past medical history of breast cancer, the prevalence of pathogenic BRCA1/2 variants fell below 5\% (2/46).

Survival bias may have affected the prevalence of pathogenic $B R C A 1 / 2$ variants detected in the subgroup of women diagnosed with ovarian cancer at 60 years or older with a family history of breast and/or ovarian cancer, prior 2012, although the difference was not statistically significant ( $24 \%$ versus $15 \%$; Fisher's exact test $\mathrm{P}=0.21)$ (Table 5 ).

210 The prevalence of pathogenic $B R C A 1 / 2$ variants was $>10 \%(101 / 463)$ in all women with a

211 Manchester BRCA Score of $\geq 15$ points, and there was a stepwise increase in prevalence as 212 the Manchester Score increased (Table 6). In contrast, in women with a Manchester Score of $213<15$ points the prevalence of pathogenic $B R C A 1 / 2$ variants was substantially $<10 \%(2 / 94)$ 214 (Table 6). 
215 Risk stratification by age alone confirmed women diagnosed with epithelial ovarian cancer 216 under the age of 30 years were unlikely to have a germline pathogenic $B R C A 1 / 2$ variant 217 (Table 7).

218

219

\section{DISCUSSION}

220 By testing germline DNA in women diagnosed with epithelial ovarian cancer across North 221 West England we found the overall prevalence of pathogenic BRCA1/2 variants exceeded $22210 \%(103 / 557)$ (Table 2). Furthermore, by separating groups according to established risk 223 factors for hereditary breast and/or ovarian cancer syndrome we found the prevalence of 224 pathogenic $B R C A 1 / 2$ variants was consistently $>10 \%$ in those women diagnosed with ovarian 225 cancer under the age of 60 years and in those diagnosed over 60 years old with either a family 226 history of breast and/or ovarian cancer or a past medical history of breast cancer (Table 2).

227 A number of studies have also assessed the prevalence of germline pathogenic $B R C A 1 / 2$ 228 variants in ovarian cancer. In an East of England series (GTEOC study), the prevalence of 229 germline pathogenic $B R C A 1 / 2$ variants amongst all high-grade serous and endometrioid 230 ovarian cancer cases was $8 \%(18 / 232)$ and increased to $12 \%(17 / 146)$ in women diagnosed $231<70$ years, but fell to $1 \%(1 / 86)$ in those aged $\geq 70$ years [19]. Similarly, in a Scottish series 232 the prevalence of pathogenic BRCA1/2 variants amongst unselected non-mucinous epithelial 233 ovarian cancer was $13.1 \%(31 / 236)$, but fell to $8.2 \%(13 / 159)$ in women diagnosed $>70$ years 234 old [20]. In an unselected series from Europe (AGO-TR-1 trial), the prevalence of pathogenic $235 B R C A 1 / 2$ variants in epithelial ovarian cancer was $20.8 \%(109 / 523)$ and fell to $10.6 \%$ in 236 women diagnosed $\geq 60$ years old, but increased to $31.9 \%(71 / 109)$ in women with a family 237 history of breast or ovarian cancer [33]. Moreover, in a large Australian study, the prevalence 
238 of pathogenic $B R C A 1 / 2$ variants in non-mucinous ovarian cancer was $14.1 \%(141 / 1,001)$, but 239 fell to $8.3 \%(38 / 457)$ in women diagnosed $\geq 61$ years old, $11.2 \%(103 / 738)$ in women without 240 a personal history of breast and 8.3\% (62/749) in women without a family history of breast 241 and/or ovarian cancer [11]. The data from these series and our study therefore suggests that, 242 three clinical features could be used to risk stratify for testing for germline $B R C A 1 / 2$ variants 243 in women diagnosed with ovarian cancer, including age at diagnosis, family history of breast 244 and/or ovarian cancer and past medical history of breast cancer. This is important if criteria 245 for selecting which patients to tests are used by funding bodies.

246 In our study, across the North West of England, selection criteria for germline BRCA1/2 247 testing was mostly based upon an individual's pathology adjusted Manchester Score of $\geq 15$ 248 points, with 17\% (94/557) falling below the 15-point threshold [30]. This scoring system 249 provides an alternative method for determining whether an individual's combined $B R C A 1$ 250 and $B R C A 2$ carrier probability is $\geq 10 \%$ (Table 1). In our series, a Manchester Score of $\geq 15$ 251 points was associated with a $>10 \%$ prevalence of pathogenic $B R C A 1 / 2$ variants, whereas a 252 Manchester Score of $<15$ points was associated with a prevalence substantially $<10 \%$. 253 Furthermore, one of the BRCA2 heterozygotes with a Manchester Score $<15$ had a strong 254 family history of prostate cancer with two first-degree relatives diagnosed at $<60$ years old, 255 giving Manchester Score of 14 (ovarian cancer $<60[5+5], 2 \times$ prostate cancer $<60[+2,+2]$ ). 256 Overall therefore, the Manchester Score provides a better trade off of sensitivity and 257 specificity than simply excluding women with sporadic ovarian cancer diagnosed after the 258 age of 60 years old.

259 Although this study is unlikely to unduly influence the debate regarding universal germline $260 B R C A 1 / 2$ testing in unselected populations of women diagnosed with ovarian cancer versus 261 those at higher-risk of inheriting a variant, we consider a number of potential problems with 
262

263

264

265

266

267

268

269

270

271

272

273

274

275

276

277

278

279

280

281

282

283

284

unselected screening beyond the obvious financial burden. Firstly, pathogenic $B R C A 1 / 2$ variants occur much less frequently in non-high-grade non-serous ovarian carcinoma $[11,19$, 20]. Indeed, somatic mutations in other genes are more commonly found in non-high-grade non-serous epithelial subtypes, including PIK3CA, PTEN, KRAS, BRAF, ERBB2 and ARID1A [34-38]. Moreover, at present PARP inhibitors are only licensed in high-grade serous and endometrioid subtypes. Therefore, there does not seem to be a biological rationale or therapeutic incentive for unselected germline $B R C A 1 / 2$ testing in non-high-grade nonserous/endometrioid subtypes.

Secondly, if unselected germline $B R C A 1 / 2$ testing becomes the prerogative of oncologists, the additional clinical expertise provided by geneticists may be lost [39-42]. No BRCA1/2 test is $100 \%$ accurate for all variants, and therefore accepting a diagnosis of $B R C A 1 / 2$ wild-type or variant of unknown clinical significance in an index case with a strong family history of cancer may be naive. Many NGS-based assays in use will identify variants in the coding regions of $B R C A 1 / 2+/-5-10$ base pairs either side of the intron-exon junction, but these assays would not detect rarer pathogenic variants such as deep intronic variants or those located in 5'-untranslated regions [43-45]. Furthermore, initially reported variants of unknown significance can be reclassified following further investigations such as segregation analysis, RNA sequencing or additional data from case-control analyses [39]. This level of genetic scrutiny only occurs in specialist genetics departments. There is therefore some concern that women diagnosed with epithelial ovarian cancer whom have a strong family history of cancer, may evade further necessary diagnostic investigations that would be performed by geneticists, if they are labelled as $B R C A 1 / 2$ wild-type or variant of unknown clinical significance by oncologists alone. 
285 Finally, by only screening for germline $B R C A 1 / 2$ variants there is a risk of missing other 286 moderate-to-low penetrance actionable cancer-predisposition genes, such as $R A D 51 C / D$, 287 BRIP-1, MLH1, MSH2/6 and PMS2 [24]. The prevalence of each individual cancer288 predisposition gene is too low in ovarian cancer to warrant screening in an unselected 289 population [46-48], however there is a risk that by focusing testing solely on $B R C A 1$ and $290 B R C A 2$, other cancer-predisposition genes will remain undetected. In the North West of 291 England, if a woman diagnosed with BRCA1/2 wild-type ovarian cancer has a Manchester 292 Score of $\geq 20$ points, she is offered extended panel testing for alternative germline variants. 293 We would therefore recommend that any patient diagnosed with ovarian cancer and a family 294 history of cancer should be referred to the local genetic department irrespective of their 295 BRCA1/2 status.

296 There are some limitations with the study. Our study was biased by including mostly women 297 with high-grade serous ovarian cancer and established risk factors for hereditary breast and/or 298 ovarian cancer syndrome. Although we are confident that our series represents an almost 299 comprehensive investigation of patients with high-grade serous ovarian cancer diagnosed 300 under the age of 60 years, we acknowledge that a comparably smaller number of women 301 diagnosed with ovarian cancer later than 60 years old were tested, especially those without 302 risk factors for hereditary breast and ovarian syndrome. Consequently, the overall prevalence 303 of germline pathogenic BRCA1/2 variants reported in our study should be interpreted in the 304 context of a selected population of women diagnosed with epithelial ovarian cancer.

305 In conclusion, the findings from our study suggest that if a $10 \%$ pre-test probability threshold 306 is required prior to germline $B R C A 1 / 2$ testing in ovarian cancer then using age at diagnosis, a 307 family history of breast and/or ovarian cancer, a past medical history of breast cancer or a 308 Manchester Score of $\geq 15$ should provide appropriate risk prediction. 


\begin{tabular}{|c|c|c|}
\hline Cancer, age at diagnosis & $B R C A 1$ & $B R C A 2$ \\
\hline $\mathrm{FBC},<30$ & 6 & 5 \\
\hline FBC, 30-39 & 4 & 4 \\
\hline FBC, 40-49 & 3 & 3 \\
\hline FBC, $50-59$ & 2 & 2 \\
\hline $\mathrm{FBC},>59$ & 1 & 1 \\
\hline $\mathrm{MBC},<60$ & 5 & 8 \\
\hline $\mathrm{MBC},>59$ & 5 & 5 \\
\hline Ovarian cancer, $<60$ & 8 & 5 \\
\hline Ovarian cancer, $>59$ & 5 & 5 \\
\hline Pancreatic cancer & 0 & 1 \\
\hline Prostate cancer, $<60$ & 0 & 2 \\
\hline Prostate cancer, $>59$ & 0 & 1 \\
\hline \multicolumn{3}{|l|}{ Pathology adjustment } \\
\hline \multicolumn{3}{|l|}{ Breast cancer (index case only) } \\
\hline Grade 3 & +2 & 0 \\
\hline Grade 2 & 0 & 0 \\
\hline Grade 1 & -2 & 0 \\
\hline ER positive & -1 & 0 \\
\hline ER negative & +1 & 0 \\
\hline Triple-negative* & +4 & 0 \\
\hline HER2 amplified ${ }^{\dagger}$ & -6 & 0 \\
\hline Ductal carcinoma in situ & -2 & 0 \\
\hline Lobular & -2 & 0 \\
\hline \multicolumn{3}{|l|}{ Ovarian cancer (any case in family ${ }^{\ddagger}$ ) } \\
\hline Mucinous, germ cell or borderline tumours & 0 & 0 \\
\hline High-grade serous, $<60$ & +2 & 0 \\
\hline Adopted (no known status in blood relatives) & +2 & +2 \\
\hline
\end{tabular}

311

312 Table 1. The Manchester Scoring System with pathology adjustment. Each individual 313 and family characteristic (from one side of the family only) is given a numerical weight and 314 these are added to give a score for each of the two genes, BRCA1 and BRCA2 [30]. Score 315 "Cancer, age at diagnosis" first and then adjust score based on "Pathology adjustment". Key: $316 *$ Also score grade in addition to triple-negative; ${ }^{\dagger}$ Also score grade and ER status in addition 317 to HER2 status; ${ }^{\ddagger}$ Only if the relative is not related to index case through more than one 318 unaffected woman aged $>60$ years; FBC, female breast cancer; MBC, male breast cancer; ER, 319 oestrogen receptor. As an example, a 34 year-old woman diagnosed with ER- HER2 320 amplified grade 3 invasive ductal carcinoma and a first-degree relative with high-grade 321 endometrioid ovarian cancer diagnosed at 63 years old would score $4+4+2+1-6+5+5=15$ 322 points. 
324

\begin{tabular}{lcc}
\hline Demographics & $\begin{array}{c}\text { Tested } \\
(\mathbf{n}=\mathbf{5 5 7})\end{array}$ & $\begin{array}{c}\text { Combined BRCA1/2 } \\
(\mathbf{n = 1 0 3})\end{array}$ \\
\hline Histology & 13 & $5(38)$ \\
Adenocarcinoma, NOS & 6 & $1(17)$ \\
Carcinosarcoma & 18 & $2(11)$ \\
Clear cell & 29 & $5^{*}(17)$ \\
Endometrioid & 10 & 0 \\
Low-grade serous & 475 & $90(19)$ \\
High-grade serous & 4 & 0 \\
Mucinous & 2 & 0 \\
Undifferentiated & 268 & $68(25)$ \\
\hline$F H_{x}$ of $B C / O C$ & 84 & $28(33)$ \\
\hline$P M H_{x}$ of $B C$ & &
\end{tabular}

325

326 Table 2. Demographic data. Data are reported as number (percentage; the denominator is 327 column 2 "Tested"). Key: $\mathrm{BC}$, breast cancer; $\mathrm{FH}_{\mathrm{x}}$, family history; NOS, not otherwise 328 specified; OC, ovarian cancer; $\mathrm{PMH}_{\mathrm{x}}$, past medical history; *All BRCA1/2 heterozygotes had 329 poorly differentiated (high-grade) endometrioid ovarian cancer. 
331

\begin{tabular}{lc}
\hline BRCA1/2 variant type & Number (\%) \\
\hline SNV & $22(21)$ \\
Insertion & $1(1)$ \\
Deletion & $55(53)$ \\
Duplication & $11(11)$ \\
Indel & $1(1)$ \\
Mosaic & $1(1)$ \\
LGR & $12(12)$ \\
$\quad$ - Deletion & 5 \\
$\quad$ - Duplication & 7 \\
\hline
\end{tabular}

332

333 Table 3. Germline BRCA1/2 variant types. Key: SNV, single nucleotide variant; indel, 334 insertion/deletion; LGR, large genomic rearrangement. 
336

\begin{tabular}{|c|c|c|c|c|}
\hline Risk factors & Tested & $B R C A 1$ & $B R C A 2$ & Combined $B R C A 1 / 2$ \\
\hline$<60 \mathrm{y} / \mathrm{o}$ & 352 & 56 & 18 & $74(21)$ \\
\hline$<60$ y/o sporadic OC & 213 & 19 & 9 & $28(13)$ \\
\hline$\geq 60 \mathrm{y} / \mathrm{o}+\mathrm{FH}_{\mathrm{x}} \mathrm{BC} / \mathrm{OC}$ & 129 & 9 & 13 & $22(17)$ \\
\hline$\geq 60 \mathrm{y} / \mathrm{o}+\mathrm{PMH}_{\mathrm{x}} \mathrm{BC}$ & 59 & 10 & 10 & $20(34)$ \\
\hline$\geq 60 \mathrm{y} / \mathrm{o}+$ sporadic $\mathrm{OC}$ & $76^{*}$ & 3 & 4 & $7 \ddagger(9)$ \\
\hline$\geq 60 \mathrm{y} / \mathrm{o}+$ sporadic $\mathrm{OC}+$ no $\mathrm{PMH}_{\mathrm{x}} \mathrm{BC}$ & 46 & 0 & $2^{\dagger}$ & $2(4)$ \\
\hline
\end{tabular}

337

338 Table 4. Risk factors for pathogenic germline $B R C A 1 / 2$ variants in epithelial ovarian 339 cancer cohort. Data are reported as number (percentage; the denominator is column 2 340 "Tested"). Key: $\mathrm{BC}$, breast cancer; $\mathrm{FH}_{\mathrm{x}}$, family history; $\mathrm{OC}$, ovarian cancer; $\mathrm{PMH}_{\mathrm{x}}$, past 341 medical history; y/o, years old; *30/76 (39\%) had a $\mathrm{PMH}_{\mathrm{x}}$ of breast cancer; ${ }^{\dagger}$ One patient had 342 a Manchester Score of 14 and one patient had a Manchester Score of $10 ; \$ 5 / 7(71 \%)$ had a $343 \mathrm{PMH}_{\mathrm{x}}$ of breast cancer. 


\begin{tabular}{|c|c|c|c|c|}
\hline Date of screening & Tested & $B R C A 1$ & $B R C A 2$ & Combined $B R C A 1 / 2$ \\
\hline Pre-January 2012 & 145 & & & $29(20)$ \\
\hline$<60 \mathrm{y} / \mathrm{o}$ & 96 & 16 & 4 & $20(21)$ \\
\hline$<60 \mathrm{y} / \mathrm{o}+$ sporadic OC & 47 & 4 & 1 & $5(11)$ \\
\hline$\geq 60 \mathrm{y} / \mathrm{o}+\mathrm{FH}_{\mathrm{x}} \mathrm{BC} / \mathrm{OC}$ & 33 & 3 & 5 & $8(24)$ \\
\hline$\geq 60 \mathrm{y} / \mathrm{o}+\mathrm{PMH}_{\mathrm{x}} \mathrm{BC}$ & 15 & 2 & 2 & $4(27)$ \\
\hline$\geq 60 \mathrm{y} / \mathrm{o}+$ sporadic OC & $16^{*}$ & 0 & $1 \uparrow$ & $1(6)$ \\
\hline$\geq 60 \mathrm{y} / \mathrm{o}+$ sporadic $\mathrm{OC}+$ no $\mathrm{PMH}_{\mathrm{x}} \mathrm{BC}$ & 8 & 0 & $1 \uparrow$ & $1(13)$ \\
\hline Post-January 2012 & 442 & & & $74(18)$ \\
\hline$<60 \mathrm{y} / \mathrm{o}$ & 256 & 40 & 14 & $54(21)$ \\
\hline$<60 \mathrm{y} / \mathrm{o}+$ sporadic OC & 166 & 15 & 8 & $23(14)$ \\
\hline$\geq 60 \mathrm{y} / \mathrm{o}+\mathrm{FH}_{\mathrm{x}} \mathrm{BC} / \mathrm{OC}$ & 96 & 6 & 8 & $14(15)$ \\
\hline$\geq 60 \mathrm{y} / \mathrm{o}+\mathrm{PMH}_{\mathrm{x}} \mathrm{BC}$ & 44 & 8 & 8 & $16(36)$ \\
\hline$\geq 60 \mathrm{y} / \mathrm{o}+$ sporadic OC & $60 \ddagger$ & 3 & 3 & $6(10) \dagger$ \\
\hline$\geq 60 \mathrm{y} / \mathrm{o}+$ sporadic $\mathrm{OC}+$ no $\mathrm{PMH}_{\mathrm{x}} \mathrm{BC}$ & 38 & 0 & $1^{\wedge}$ & $1(3)$ \\
\hline
\end{tabular}

346

Table 5. Evaluation of survival bias according to date of ovarian cancer diagnosis. Data 348 are reported as number (percentage; the denominator is column 2 "Tested"). Key: BC, breast 349 cancer; $\mathrm{FH}_{\mathrm{x}}$, family history; $\mathrm{OC}$, ovarian cancer; $\mathrm{PMH}_{\mathrm{x}}$, past medical history; y/o, years old; $350 * 8 / 16(50 \%)$ had a $\mathrm{PMH}_{\mathrm{x}}$ of $\mathrm{BC} ;{ }^{\dagger}$ the same patient (Manchester Score 14$) ; \ddagger 22 / 60(37 \%)$ 351 had a $\mathrm{PMH}_{\mathrm{x}}$ of $\mathrm{BC} ;{ }^{\dagger} 5 / 6(83 \%)$ had a $\mathrm{PMH}_{\mathrm{x}}$ of $\mathrm{BC} ;$; $1 / 6(17 \%)$ had a Manchester Score $<15$ 352 and $5 / 6(83 \%)$ had a Manchester Score $\geq 15$; $\wedge$ Patient had a Manchester Score of 10 . All 353 germline $B R C A 1 / 2$ testing took place after $1^{\text {st }}$ June 2013 . There was no evidence of survival 354 bias between cohorts (pre- and post-January 2012). 
356

\begin{tabular}{ccccc}
\hline Manchester Score & Tested & BRCA1 & BRCA2 & Combined BRCA1/2 \\
\hline$<15$ & 94 & 0 & 2 & $2(2)$ \\
$15-19$ & 298 & 27 & 16 & $43(14)$ \\
$20-29$ & 133 & 25 & 11 & $36(27)$ \\
$30-40$ & 20 & 7 & 5 & $12(60)$ \\
$40+$ & 12 & 9 & 1 & $10(83)$ \\
\hline
\end{tabular}

357

358 Table 6. Manchester BRCA Score. The Manchester Score is reported in points. Data are 359 reported as number (percentage; the denominator is column 2 "Tested"). 
361

\begin{tabular}{ccccc}
\hline Age & Tested & $\boldsymbol{B R C A 1}$ & $\boldsymbol{B R C A 2}$ & Combined $\boldsymbol{B R C A 1 / 2}$ \\
\hline$<30$ & 6 & 0 & 0 & $0(0)$ \\
$30-39$ & 20 & 4 & 1 & $5(25)$ \\
$40-49$ & 113 & 22 & 5 & $27(24)$ \\
$50-59$ & 213 & 30 & 12 & $42(20)$ \\
$60-69$ & $140^{*}$ & 9 & 12 & $21(15)$ \\
$\geq 70$ & $65^{\dagger}$ & 3 & 5 & $8(12)$ \\
\hline
\end{tabular}

362

363 Table 7. Prevalence of pathogenic germline $B R C A 1 / 2$ variants according to age at 364 diagnosis. Data is reported as number (percentage; the denominator is column 2 "Tested"). 365 Age is reported in years. Key: *84/140 (60\%) had a family history of breast or ovarian cancer 366 and 37/140 (26\%) had a past medical history of breast cancer; $\dagger$ 45/65 (69\%) had a family 367 history of breast or ovarian cancer and 22/65 (34\%) had a past medical history of breast 368 cancer. 


\section{REFERENCES}

371 1. Bray F, Ferlay J, Soerjomataram I, Siegel RL, Torre LA, Jemal A. Global cancer 372 statistics 2018: GLOBOCAN estimates of incidence and mortality worldwide for 36 cancers 373 in 185 countries. CA Cancer J Clin. 2018;68(6):394-424.

374 2. National Comprehensive Cancer Network. NCCN clinical practice guidelines in 375 oncology: ovarian cancer version 2 [available at 376 https://www.nccn.org/professionals/physician_gls/pdf/ovarian.pdf2018]

377 3. ESMO Guidelines Working Group. Newly diagnosed and relapsed epithelial ovarian 378 carcinoma: ESMO Clinical Practice Guidelines for diagnosis, treatment and follow-up. Ann 379 Oncol. 2013;24 Suppl 6:vi24-32.

380 4. Morgan RD, Clamp AR, Evans DGR, Edmondson RJ, Jayson GC. PARP inhibitors in 381 platinum-sensitive high-grade serous ovarian cancer. Cancer Chemother Pharmacol. $382 \quad 2018 ; 81(4): 647-58$.

383 5. ARIEL3 investigators. Rucaparib maintenance treatment for recurrent ovarian 384 carcinoma after response to platinum therapy: a randomised, double-blind, placebo385 controlled, phase 3 trial. Lancet. 2017;390(10106):1949-61.

386 6. ENGOT-OV16/NOVA investigators. Niraparib Maintenance Therapy in Platinum387 Sensitive,Recurrent Ovarian Cancer. N Engl J Med. 2017;375(22):2154-2164.

388 7. SOLO2/ENGOT-Ov21 investigators. Olaparib tablets as maintenance therapy in 389 patients with platinum-sensitive, relapsed ovarian cancer and a BRCA1/2 mutation: a double390 blind, randomised, placebo-controlled, phase 3 trial. Lancet Oncol. 2017;18(9):1274-84.

391 8. Ledermann JA, Harter P, Gourley C, Friedlander M, Vergote I, Rustin G, Scott CL, 392 Meier W, Shapira-Frommer R, Safra T, Matei D, Fielding A, Spencer S, Doughtery B, Orr 393 M, Hodgson D, Barrett JC, Matulonis U. Olaparib maintenance therapy in patients with 
394

395

396

397

398

399

400

401

402

403

404

405

406

407

408

409

410

411

412

413

414

415

416

417

418

platinum-sensitive relapsed serous ovarian cancer: a preplanned retrospective analysis of outcomes by BRCA status in a randomised phase 2 trial. Lancet Oncol 2014;15(8):852-61

9. Moore K, Colombo N, Scambia G, Kim BG, Oaknin A, Friedlander M, Lisyanskaya A, Floquet A, Leary A, Sonke GS, Gourley C, Banerjee S, Oza A, González-Martín A, Aghajanian C, Bradley W, Mathews C, Liu J, Lowe ES, Bloomfield R, DiSilvestro P.. Maintenance Olaparib in Patients with Newly Diagnosed Advanced Ovarian Cancer. N Engl J Med. 2018.

10. Swisher EM, Lin KK, Oza AM, Scott CL, Giordano H, Sun J, Konecny GE, Coleman RL, Tinker AV, O'Malley DM, Kristeleit RS, Ma L, Bell-McGuinn KM, Brenton JD, Cragun JM, Oaknin A, Ray-Coquard I, Harrell MI, Mann E, Kaufmann SH, Floquet A, Leary A, Harding TC, Goble S, Maloney L, Isaacson J, Allen AR, Rolfe L, Yelensky R, Raponi M, McNeish IA. Rucaparib in relapsed, platinum-sensitive high-grade ovarian carcinoma: an international, multicentre, open-label, phase 2 trial. Lancet Oncology. 2017;18(1):75-87.

11. Alsop K, Fereday S, Meldrum C, deFazio A, Emmanuel C, George J, Dobrovic A, Birrer MJ, Webb PM, Stewart C, Friedlander M, Fox S, Bowtell D, Mitchell G. BRCA mutation frequency and patterns of treatment response in BRCA mutation-positive women with ovarian cancer: a report from the Australian Ovarian Cancer Study Group. J Clin Oncol. 2012;30(21):2654-63.

12. Norquist BM, Harrell MI, Brady MF, Walsh T, Lee MK, Gulsuner S, Bernards SS, Casadei S, Yi Q, Burger RA, Chan JK, Davidson SA, Mannel RS, DiSilvestro PA, Lankes HA, Ramirez NC, King MC, Swisher EM, Birrer MJ. Inherited Mutations in Women With Ovarian Carcinoma. JAMA Oncol. 2016;2(4):482-90.

13. Zhang S, Royer R, Li S, McLaughlin JR, Rosen B, Risch HA, Fan I, Bradley L, Shaw PA, Narod SA. Frequencies of BRCA1 and BRCA2 mutations among 1,342 unselected patients with invasive ovarian cancer. Gynecol Oncol. 2011;121(2):353-7. 
419 14. Walsh T, Casadei S, Lee MK, Pennil CC, Nord AS, Thornton AM, Roeb W, Agnew 420 KJ, Stray SM, Wickramanayake A, Norquist B, Pennington KP, Garcia RL, King MC, 421 Swisher EM. Mutations in 12 genes for inherited ovarian, fallopian tube, and peritoneal 422 carcinoma identified by massively parallel sequencing. Proc Natl Acad Sci U S A. $423 \quad 2011 ; 108(44): 18032-7$.

424 15. Pennington KP, Walsh T, Harrell MI, Lee MK, Pennil CC, Rendi MH, Thornton A, 425 Norquist BM, Casadei S, Nord AS, Agnew KJ, Pritchard CC, Scroggins S, Garcia RL, King 426 MC, Swisher EM. Germline and somatic mutations in homologous recombination genes 427 predict platinum response and survival in ovarian, fallopian tube, and peritoneal carcinomas. 428 Clin Cancer Res. 2014;20(3):764-75.

429 16. Kurman RJ, Herrington CS, Carcangiu ML. WHO Classification of Tumours of 430 Female Reproductive Organs (IARC WHO Classification of Tumours - Fourth Edition) 2014. 431 17. Jayson GC, Kohn EC, Kitchener HC, Ledermann JA. Ovarian cancer. Lancet. $432 \quad 2014 ; 384(9951): 1376-88$.

433 18. Rahman B, Lanceley A, Kristeleit RS, Ledermann JA, Lockley M, McCormack M, 434 Mould T, Side L. Mainstreamed genetic testing for women with ovarian cancer: first-year 435 experience. J Med Genet. 2018.

436 19. Plaskocinska I, Shipman H, Drummond J, Thompson E, Buchanan V, Newcombe B, 437 Hodgkin C, Barter E, Ridley P, Ng R, Miller S, Dann A, Licence V, Webb H, Tan LT, Daly 438 M, Ayers S, Rufford B, Earl H, Parkinson C, Duncan T, Jimenez-Linan M, Sagoo GS, Abbs 439 S, Hulbert-Williams N, Pharoah P, Crawford R, Brenton JD, Tischkowitz M. New paradigms 440 for BRCA1/BRCA2 testing in women with ovarian cancer: results of the Genetic Testing in 441 Epithelial Ovarian Cancer (GTEOC) study. J Med Genet. 2016;53(10):655-61.

442 20. Rust K, Spiliopoulou P, Tang CY, Bell C, Stirling D, Phang T, Davidson R, Mackean 443 M, Nussey F, Glasspool RM, Reed NS, Sadozye A, Porteous M, McGoldrick T, Ferguson M, 
444 Miedzybrodzka Z, McNeish IA, Gourley C. Routine germline BRCA1 and BRCA2 testing in 445 patients with ovarian carcinoma: analysis of the Scottish real-life experience. BJOG.

446

447

448

449

450

451

452

453

454

455

456

457

458

459

460

461

462

463

464

465

466 2018;125(11):1451-1458.

21. George A, Riddell D, Seal S, Talukdar S, Mahamdallie S, Ruark E, Cloke V, Slade I, Kemp Z, Gore M, Strydom A, Banerjee S, Hanson H, Rahman N. Implementing rapid, robust, cost-effective, patient-centred, routine genetic testing in ovarian cancer patients. Sci Rep. 2016;6:29506.

22. Colombo N, Huang G, Scambia G, Chalas E, Pignata S, Fiorica J, Van Le L, Ghamande S, González-Santiago S, Bover I, Graña Suárez B, Green A, Huot-Marchand P, Bourhis Y, Karve S, Blakeley C. Evaluation of a Streamlined Oncologist-Led BRCA Mutation Testing and Counseling Model for Patients With Ovarian Cancer. J Clin Oncol. 2018;36(13):1300-7.

23. Kentwell M, Dow E, Antill Y, Wrede CD, McNally O, Higgs E, Hamilton A, Ananda S, Lindeman GJ, Scott CL. Mainstreaming cancer genetics: A model integrating germline BRCA testing into routine ovarian cancer clinics. Gynecol Oncol. 2017;145(1):130-6.

24. Rahman N. Realizing the promise of cancer predisposition genes. Nature. 2014;505(7483):302-8.

25. FIGO Committee on Gynecologic Oncology. FIGO's staging classification for cancer of the ovary, fallopian tube, and peritoneum. J Gynecol Oncol. 2015;26(2):87-9.

26. ACMG Laboratory Quality Assurance Committee. Standards and guidelines for the interpretation of sequence variants: a joint consensus recommendation of the American College of Medical Genetics and Genomics and the Association for Molecular Pathology. Genet Med. 2015;17(5):405-24. 
467 27. EMBRACE; kConFab Investigators; Cancer Genome Atlas Research Network. 468 Association between BRCA1 and BRCA2 mutations and survival in women with invasive 469 epithelial ovarian cancer. JAMA. 2012;307(4):382-90.

470 28. McLaughlin JR, Rosen B, Moody J, Pal T, Fan I, Shaw PA, Risch HA, Sellers TA, 471 Sun P, Narod SA. Long-term ovarian cancer survival associated with mutation in BRCA1 or 472 BRCA2. J Natl Cancer Inst. 2013;105(2):141-8.

473 29. Schouten JP, McElgunn CJ, Waaijer R, Zwijnenburg D, Diepvens F, Pals G. Relative 474 quantification of 40 nucleic acid sequences by multiplex ligation-dependent probe 475 amplification. Nucleic Acids Res. 2002;30(12):e57.

476 30. Evans DG, Harkness EF, Plaskocinska I, Wallace AJ, Clancy T, Woodward ER, 477 Howell TA, Tischkowitz M, Lalloo F. Pathology update to the Manchester Scoring System 478 based on testing in over 4000 families. J Med Genet. 2017;54(10):674-81.

479 31. Evans DG, Eccles DM, Rahman N, Young K, Bulman M, Amir E, Shenton A, Howell 480 A, Lalloo F. A new scoring system for the chances of identifying a BRCA1/2 mutation 481 outperforms existing models including BRCAPRO. J Med Genet. 2004;41(6):474-80.

482 32. Couch FJ, Hart SN, Sharma P, Toland AE, Wang X, Miron P, Olson JE, Godwin AK, 483 Pankratz VS, Olswold C, Slettedahl S, Hallberg E, Guidugli L, Davila JI, Beckmann MW, 484 Janni W, Rack B, Ekici AB, Slamon DJ, Konstantopoulou I, Fostira F, Vratimos A, 485 Fountzilas G, Pelttari LM, Tapper WJ, Durcan L, Cross SS, Pilarski R, Shapiro CL, Klemp J, 486 Yao S, Garber J, Cox A, Brauch H, Ambrosone C, Nevanlinna H, Yannoukakos D, Slager 487 SL, Vachon CM, Eccles DM, Fasching PA. Inherited mutations in 17 breast cancer 488 susceptibility genes among a large triple-negative breast cancer cohort unselected for family 489 history of breast cancer. J Clin Oncol. 2015;33(4):304-11.

490 33. Harter P, Hauke J, Heitz F, Reuss A, Kommoss S, Marmé F, Heimbach A, Prieske K, 491 Richters L, Burges A, Neidhardt G, de Gregorio N, El-Balat A, Hilpert F, Meier W, Kimmig 
492

493

494

495

496

497

498

499

500

501

502

503

504

505

506

507

508

509

510

511

512

513

514

515

516

R, Kast K, Sehouli J, Baumann K, Jackisch C, Park-Simon TW, Hanker L, Kröber S, Pfisterer J, Gevensleben H, Schnelzer A, Dietrich D, Neunhöffer T, Krockenberger M, Brucker SY, Nürnberg P, Thiele H, Altmüller J, Lamla J, Elser G, du Bois A, Hahnen E, Schmutzler R. Prevalence of deleterious germline variants in risk genes including BRCA1/2 in consecutive ovarian cancer patients (AGO-TR-1). PLoS One. 2017;12(10):e0186043.

34. Kuo KT, Mao TL, Jones S, Veras E, Ayhan A, Wang TL, Glas R, Slamon D, Velculescu VE, Kurman RJ, Shih IeM. Frequent activating mutations of PIK3CA in ovarian clear cell carcinoma. Am J Pathol. 2009;174(5):1597-601.

35. McAlpine JN, Wiegand KC, Vang R, Ronnett BM, Adamiak A, Kobel M, Kalloger SE, Swenerton KD, Huntsman DG, Gilks CB, Miller DM. HER2 overexpression and amplification is present in a subset of ovarian mucinous carcinomas and can be targeted with trastuzumab therapy. BMC Cancer. 2009;9:433.

36. Australian Ovarian Cancer Study Group. Mutational landscape of mucinous ovarian carcinoma and its neoplastic precursors. Genome Med. 2015;7(1):87.

37. Jones S, Wang TL, Shih IeM, Mao TL, Nakayama K, Roden R, Glas R, Slamon D, Diaz LA Jr, Vogelstein B, Kinzler KW, Velculescu VE, Papadopoulos N. Frequent mutations of chromatin remodeling gene ARID1A in ovarian clear cell carcinoma. Science. 2010;330(6001):228-31.

38. Ovarian Cancer Association Consortium. Association between endometriosis and risk of histological subtypes of ovarian cancer: a pooled analysis of case-control studies. Lancet Oncol. 2012;13(4):385-94.

39. Byers H, Wallis Y, van Veen EM, Lalloo F, Reay K, Smith P, Wallace AJ, Bowers N, Newman WG, Evans DG. Sensitivity of BRCA1/2 testing in high-risk breast/ovarian/male breast cancer families: little contribution of comprehensive RNA/NGS panel testing. Eur J Hum Genet. 2016;24(11):1591-7. 
517 40. Wappenschmidt B, Becker AA, Hauke J, Weber U, Engert S, Köhler J, Kast K, 518 Arnold N, Rhiem K, Hahnen E, Meindl A, Schmutzler RK. Analysis of 30 putative BRCA1 519 splicing mutations in hereditary breast and ovarian cancer families identifies exonic splice 520 site mutations that escape in silico prediction. PLoS One. 2012;7(12):e50800.

521 41. Montalban G, Bonache S, Moles-Fernández A, Gisbert-Beamud A, Tenés A, Bach V, 522 Carrasco E, López-Fernández A, Stjepanovic N, Balmaña J, Diez O, Gutiérrez-Enríquez S. 523 Screening of BRCA1/2 deep intronic regions by targeted gene sequencing identifies the first 524 germline BRCA1 variant causing pseudoexon activation in a patient with breast/ovarian 525 cancer. J Med Genet. 2018.

526 42. ENIGMA consortium. Assessment of the functional impact of germline BRCA1/2 527 variants located in non-coding regions in families with breast and/or ovarian cancer 528 predisposition. Breast Cancer Res Treat. 2018;168(2):311-25.

529 43. Evans DGR, van Veen EM, Byers HJ, Wallace AJ, Ellingford JM, Beaman G, 530 Santoyo-Lopez J, Aitman TJ, Eccles DM, Lalloo FI, Smith MJ, Newman W. A Dominantly 531 Inherited 5' UTR Variant Causing Methylation-Associated Silencing of BRCA1 as a Cause of 532 Breast and Ovarian Cancer. Am J Hum Genet. 2018;103(2):213-20.

533 44. Anczukow O, Buisson M, Leone M, Coutanson C, Lasset C, Calender A, Sinilnikova 534 OM, Mazoyer S. BRCA2 deep intronic mutation causing activation of a cryptic exon: 535 opening toward a new preventive therapeutic strategy. Clin Cancer Res. 2012;18(18):4903-9.

536 45. kConFab Investigators. Splicing and multifactorial analysis of intronic BRCA1 and 537 BRCA2 sequence variants identifies clinically significant splicing aberrations up to 12 538 nucleotides from the intron/exon boundary. Hum Mutat. 2011;32(6):678-87.

539 46. Ovarian Cancer Association Consortium. Germline Mutations in the BRIP1, BARD1, 540 PALB2, and NBN Genes in Women With Ovarian Cancer. J Natl Cancer Inst. 2015;107(11). 
541 47. Song H, Dicks E, Ramus SJ, Tyrer JP, Intermaggio MP, Hayward J, Edlund CK, 542 Conti D, Harrington P, Fraser L, Philpott S, Anderson C, Rosenthal A, Gentry-Maharaj A, 543 Bowtell DD, Alsop K, Cicek MS, Cunningham JM, Fridley BL, Alsop J, Jimenez-Linan M, 544 Høgdall E, Høgdall CK, Jensen A, Kjaer SK, Lubiński J, Huzarski T, Jakubowska A, 545 Gronwald J, Poblete S, Lele S, Sucheston-Campbell L, Moysich KB, Odunsi K, Goode EL, 546 Menon U, Jacobs IJ, Gayther SA, Pharoah PD. Contribution of Germline Mutations in the 547 RAD51B, RAD51C, and RAD51D Genes to Ovarian Cancer in the Population. J Clin Oncol. $548 \quad 2015 ; 33(26): 2901-7$.

549 48. Norquist BM, Brady MF, Harrell MI, Walsh T, Lee MK, Gulsuner S, Bernards SS, 550 Casadei S, Burger RA, Tewari KS, Backes F, Mannel RS, Glaser G, Bailey C, Rubin S, 551 Soper J, Lankes HA, Ramirez NC, King MC, Birrer MJ, Swisher EM. Mutations in 552 Homologous Recombination Genes and Outcomes in Ovarian Carcinoma Patients in GOG 553 218: An NRG Oncology/Gynecologic Oncology Group Study. Clin Cancer Res. $554 \quad 2018 ; 24(4): 777-83$. 